\title{
WestVirginiaUniversity
}

THE RESEARCH REPOSITORY @ WVU

Volume 45 | Issue 3

Article 12

April 1939

\section{The Law of Treaties; British Practice and Opinions}

Carl M. Frasure

West Virginia University

Follow this and additional works at: https://researchrepository.wvu.edu/wvlr

Part of the International Law Commons

\section{Recommended Citation}

Carl M. Frasure, The Law of Treaties; British Practice and Opinions, 45 W. Va. L. Rev. (1939).

Available at: https://researchrepository.wvu.edu/wvlr/vol45/iss3/12

This Book Review is brought to you for free and open access by the WVU College of Law at The Research Repository @ WVU. It has been accepted for inclusion in West Virginia Law Review by an authorized editor of The Research Repository @WVU. For more information, please contact ian.harmon@mail.wvu.edu. 
The Law of Treatres; British Practice and Opinions. By Arnold Duncan McNair, New York, N. Y. Columbia University Press, 1938. Pp. xxix, 578.

The low estate to which international law has fallen during the last several years cannot affect the importance of knowing how such law has been interpreted and applied in the past by the proper authorities in the more important national states of the world. It is with this thought in mind that Columbia University is sponsoring the study of this question in various countries at the present time.

For the United States we already have the monumental works of two international lawyers, - John Bassett Moore, Digest of International Law and Charles C. Hyde, International Law, Chiefly as Interpreted and Applied by the United States. Professor McNair, Vice-Chancellor of the University of Liverpool and formerly the Whewell Professor of International Law at Cambridge, has now performed such a service for Great Britain in a volume whose purpose is to "state the practice of the United Kingdom in the matter of Treaties, their Conclusion, their Interpretation, the Scope of their Operation, their Termination and Modification, and the law that is relevant to these topies in so far as it can be gathered from United Kingdom sources." The publication of Professor McNair's book has been made possible by a grant from the Columbia. University Council for Research in the Social Sciences.

Professor McNair makes clear that his work is an unofficial attempt to express views on international law that have been, or are likely to be, expressed in British official quarters. The only official part of his volume is to be found in the documents that are quoted to show the legal advice given in a particular instance. It does not follow, however, that the same views will be held in future cases. It should also be noted that the action of a government in a certain case did not necessarily follow the advice of its legal staff; expediency may have dictated a different policy. Yet, it is useful to international lawyers to know what legal advice the government received. Also Professor MeNair has dealt mainly with only two of the many sources to which advisers of the British Government would turn before giving legal advice, - namely, the opinions of their predecessors and the decisions of the British courts. Despite these limitations Professor McNair's volume will be welcomed as a further effort to improve the status of international law. 
The volume is divided into four parts. Part I deals with the conclusion of treaties with a discussion of such matters as terminology, constitutional requirements, form, ratification, accession, reservations, and registration. Part II treats the interpretation of treaties with reference to such questions as the functions of municipal courts, the intention of the parties and implied terms or conditions. Part III is concerned with the scope of the operation of treaties as they affect "third parties" and the nationals of the con. tracting states. Part IV covers the matter of termination and modification of treaties, with particular reference to changed conditions from those under which 'a treaty is negotiated.

The scope of Professor McNair's work is further evidenced in the fact that he cites more than one hundred cases, refers to nearly two hundred law officers' reports, and makes use of more than two hundred and fifty treaties extending from 1373 down to 1936.

Professor McNair's study is a worthy companion of the works of Professors Moore and Hyde. He has set a high standard of research and thoroughness for succeeding volumes dealing with the same subject as it is treated in other countries. Such studies will go a long way to clear up much misunderstanding existing today in the field we call international law.

West Virginia University, Cari M. Frasure.

Morgantown, West Virginia. 